Gulawentah: Jurnal Studi Sosial

ISSN 2528-6293 (Print); ISSN 2528-6871 (Online)

Vol. 4, No. 2, Desember 2019, Hal 93-101

Tersedia Online: http://e-journal.unipma.ac.id/index.php/gulawentah

\title{
Peningkatan Motivasi dan Prestasi Belajar dengan Multimedia pada Pembelajaran IPS di Sekolah Dasar
}

\author{
Tumini \\ SD Negeri 1 Ngadisanan, Sambit, Ponorogo, Indonesia \\ Email: tuminibamb@gmail.com
}

\begin{abstract}
Abstrak
Penelitian ini bertujuan untuk 1) Mendeskripsikan pembelajaran IPS dengan multimedia sebagai upaya meningkatkan motivasi belajar siswa di Kelas IV SDN 1 Ngadisanan 2) Mendiskripsikan pembelajaran IPS dengan multimedia dalam meningkatkan prestasi belajar siswa di Kelas IV SDN 1 Ngadisanan. Penelitian ini dilaksanakan di SD Negeri 1 Ngadisanan, Sambit, Ponorogo selama 6 bulan tahun 2019. Pengambilan data secara diskriptif kualitatif dengan jenis penelitian tindakan kelas (PTK). Hasil penelitian menunjukkan bahwa dengan multimedia dapat meningkatkan motivasi dan prestasi pembelajaran IPS kelas IV SD Negeri 1 Ngadisanan. Peningkatan ini dibuktikan tahap pratindakan, menunjukkan bahwa prestasi belajar siswa kelas IV pada mata pelajaran IPS tergolong rendah. Nilai rata-rata kelas mencapai 65,94 sedangkan ketuntasan belajar sebesar $44 \%$. Pada siklus I motivasi siswa mencapai $73 \%$ sedang rata-rata prestasi siswa 69,81. Pada siklus II motivasi siswa meningkat menjadi $85 \%$ sudah memenuhi indikator dari motivasi siswa yaitu $80 \%$ sedangkan nilai prestasi siswa 77,70. Prestasi belajar pada siklus II telah memenuhi indikator keberhasilan karena dari $\leq 75 \%$ siswa sudah mencapai KKM.
\end{abstract}

Kata kunci: Motivasi; Prestasi Belajar; Multimedia IPS

\section{Increasing Motivation and Learning Achievement with Multimedia in Social Studies Learning in Primary Schools}

\section{Abstract}

This study aims to 1) Describe social studies learning with multimedia as an effort to improve student motivation in GradeIV SDN 1 Ngadisanan 2) Describe social studies learning with multimedia in improving student achievement ofGrade IV SDN 1 Ngadisanan. This research was conducted in SD Negeri 1 Ngadisanan, Sambit, Ponorogo for 6 months in 2019. Data was collected with qualitative descriptive type of classroom action research (CAR/PTK). The results showed that multimedia could increase motivation and achievement in social studies learning in grade IV at SD Negeri 1 Ngadisanan. This increase was proven by the pre-action stage, indicating that the learning achievement of fourth grade students in social studies subjects was low. The average grade reaches 65.94 while learning completeness is $44 \%$. In the first cycle (Cycle I)students' motivation reached $73 \%$ while the average student achievement was 69.81 . In the second cycle(cycle II) students' motivation increased to $85 \%$ had met the indicators of student motivation which is $80 \%$ while the achievement value of students was 77.70. Learning achievement in cycle II has met the indicator of success because of $\leq 75 \%$ of students have reached the KKM (minimal completeness criteria).

Keywords: Javanese Culture; Cakepan; Wedding ceremony

DOI: 10.25273/gulawentah.v4i2.5556

Copyright ( 2019 Universitas PGRI Madiun

All rights reserved. 


\section{Pendahuluan}

Pendidikan merupakan salah satu bagian penting dalam kehidupan umat manusia. Pendidikan berfungsi untuk mengembangkan sumber daya manusia yang berorientasi meningkatkan kualitas kehidupan. Pendidikan tidak semata-mata berusaha untuk mencapai hasil belajar, tetapi bagaimana memperoleh hasil atau proses belajar yang terjadi pada diri anak. Suasana belajar dan pembelajaran itu diarahkan agar peserta didik dapat mengembangkan potensi dirinya, ini berarti proses pendidikan itu harus berorientasi kepada siswa (student active learning). Akhir dari proses pendidikan adalah kemampuan anak memiliki kekuatan spiritual keagamaan, pengendalian diri, kepribadian, kecerdasan, akhlak mulia, serta keterampilan yang diperlukan dirinya, masyarakat, bangsa, dan negara. Hal ini berarti proses pendidikan berujung kepada pembentukan sikap, pengembangan kecerdasan atau intelektual, serta pengembangan keterampilan anak sesuai dengan kebutuhan.

Menurut Sardiman (2012) motivasi belajar adalah keseluruhan daya penggerak didalam diri siswa yang menimbulkan kegiatan belajar, yang menjamin kelangsungan dari kegiatan belajar dan memberikan arah pada kegiatan belajar, sehingga tujuan yang dikehendaki oleh subjek belajar itu dapat tercapai. Motivasi belajar akan mendorong siswa untuk belajar dengan giat, memberikan arah pada kegiatan belajarnya sehingga tujuan belajarnya akan tercapai. Motivasi belajar merupakan merupakan faktor psikis yang bersifat non intelektual dan berperan dalam hal menumbuhkan semangat belajar untuk individu. Lengkapnya dapat disimpulkan bahwa pengertian motivasi belajar adalah keseluruhan daya penggerak baik dari dalam diri maupun dari luar siswa (dengan menciptakan serangkaian usaha untuk menyediakan kondisi-kondisi tertentu) yang menjamin kelangsungan dan memberikan arah pada kegiatan belajar, sehingga tujuan yang dikehendaki oleh subjek belajar itu dapat tercapai. Jadi proses pembelajaran akan semakin produktif jika siswa memiliki motivasi belajar yang tinggi. Motivasi akan mendorong siswa untuk belajar dengan giat sehingga meningkatkan prestasi belajarnya (Kadji, 2012; Uno, 2008).

Menurut Hamalik (2000) menyatakan bahwa prestasi belajar merupakan sesuatu yang dibutuhkan seseorang untuk mengetahui kemampuan setelah melakukan kegiatan yang bersifat belajar, karena prestasi adalah hasil belajar yang mengandung unsur penilaian, hasil usaha kerja dan ukuran kecakapan yang dicapai suatu saat. Prestasi belajar IPS dapat diketahui dari hasil belajar siswa dalam mengerjakan soal evaluasi pada mata pelajaran IPS. Hasil belajar merupakan perubahan yang terjadi pada diri siswa baik yang menyangkut aspek, kognitif, afektif, dan psikomotor sebagai hasil dari kegiatan belajar (Susanto, 2013). Berdasarkan beberapa pendapat diatas dapat disimpulkan bahwa prestasi belajar merupakan hasil yang dicapai oleh individu setelah mengalami proses belajar dalam jangka waktu tertentu. Prestasi belajar yang ditampilkan dengan nilai atau angka dibuat guru berdasarkan pedoman penilaian pada masing-masing siswa berbeda, berdasarkan tingkat penguasaan kompetensi yang telah ditetapkan. Faktor-faktor yang mempengaruhi prestasi belajar adalah 1) Faktor-faktor dalam diri individu meliputi : a) Aspek jamaniah mencakup kondisi dan kesehatan jasmani dari individu, b) Aspek psikis atau rohaniah individu, c) Kondisi intelektual individu, d) Kondisi sosial menyangkut hubungan dengan orang lain, e) Motivasi belajar yang kuat, dan f) Keterampilan-keterampilan yang dimilikinya. 2) Faktorfaktor lingkungan, keberhasilan belajar juga sangat dipengaruhi oleh faktor-faktor di luar diri siswa, baik faktor fisik maupun sosial-psikologis yang berada pada lingkungan keluarga, sekolah, dan masyarakat.

Kenyataan selama ini masih banyak penggunaan model serta metode pembelajaran yang masih bersifat konvensional, belum adanya improvisasi menjadi pembelajaran yang modern sesuai dengan tuntutan zaman dan lingkungan sekitar dimana siswa berada. Guru kelas dalam menyampaikan materi masih belum menggunakan media pembelajaran. Dalam penyampaian materi guru masih dominan menggunakan metode ceramah atau penyampaian materi secara verbal. Selama proses pembelajaran yang telah berlangsung, siswa merasa kesulitan memahami materi yang sifatnya abstrak. Selain itu, guru masih kurang aktif melibatkan siswa dalam proses pembelajaran, sehingga kompetensi afektif siswa belum tercapai sepenuhnya. Pada awal pembelajaran siswa masih memperhatikan, menjelang pertengahan terlihat siswa cenderung bosan 
mengikuti pelajaran. Untuk itu perlu adanya pembaharuan agar proses dan hasil pembelajaran bisa mencapai tujuan yang optimal, salah satu caranya adalah penggunaan multimedia pembelajaran agar materi pembelajaran bisa lebih konkrit. Penerapam ICT dalam pembelajaran di era perkembangan teknologi yang semakin pesat merupakan sebuah keniscayaan (Santoso, Yusro, Malawi, Hanif, \& Kokotiasa, 2019). Beberapa contoh model pembelajaran yang modern yang cocok digunakan dalam pembelajaran IPS di antaranya model pembelajaran contextual teaching and learning, cooperative learning, quantum learning, active learning, serta teknologi dan masyarakat (Huda, 2016; Nurdiana, 2016). Beberapa model pembelajaran tersebut sebagai upaya pembaharuan dalam pembelajaran IPS.

Proses penyampaian materi pada pembelajaran IPS di kelas IV SDN 1 Ngadisanan menggunakan multimedia berbasis powerpoint. Multimedia adalah suatu sistem penyampaian pesan menggunakan berbagai jenis pengajaran yang membentuk suatu unit atau paket (Cecep \& Bambang, 2011). Contoh dari multimedia adalah satu modul pembelajaran yang terdiri atas bahan cetak, bahan audio, dan bahan audiovisual yang dikemas dalam satu paket.Multimedia berbasis powerpoint didalamnya meliputi objek teks, gambar, video dan hyperlink yang digunakan secara terintegrasi . Penggabungan objek-objek tersebut akan menjadi satu kesatuan atau terintegrasi antara satu sama lain dalam proses pembelajaran di kelas. Dalam menyajian materi IPS secara verbal menggunakan metode ceramah dan secara pictorial menggunakan proyeksi grafis yang meliputi gambar dan video (R. Mayer \& Mayer, 2005; R. E. Mayer, 2002; Najjar, 1996). Sedangkan materi yang disampaikan dalam penelitian ini tentang Keragaman Suku Bangsa dan Agama di Negeriku, berikut penjelasannya. Multimedia berbasis powerpoint ini digunakan untuk menjelaskan materi-materi yang bersifatnya teoritis dalam pembelajaran klasikal, baik untuk kelompok kecil maupun besar (Setiawan, 2007). Seperti yang kita ketahui pada umumnya mata pelajaran IPS memiliki materi yang cenderung abstrak dan bersifat teoritis. Apabila guru dalam menyampaikan materi hanya menggunakan metode ceramah saja, pasti akan membuat siswa menjadi cepat bosan. Multimedia ini cukup efektif sebab menggunakan media projector (LCD/ Viewer) yang memiliki jangkauan pancar cukup besar apabila dipasang di dalam kelas. Proses pembelajaran demikian itu, dapat membuat siswa yang duduk di depan sampai paling belakang akan memperhatikan proses pembelajaran

Hasil survei bulan Januari 2019 kepada siswa kelas IV di SDN 1 Ngadisanan, menunjukkan bahwa para siswa tersebut merasa kesulitan belajar IPS karena pembelajaran cenderung berupa pemahaman dan cakupan materi yang luas. Motivasi siswa dalam pembelajaran masih rendah sehingga siswa mengalami kesulitan dalam belajar. Kesulitan belajar siswa juga dipengaruhi oleh beberapa faktor seperti kurang konsentrasinya siswa saat belajar, siswa terlihat berbicara sendiri saat pembelajaran berlangsung dan ada siswa yang senang menjaili teman sebangkunya saat pelajaran berlangsung. Jika keadaan ini dibiarkan terus menerus akan membuat siswa yang bersangkutan ketinggalan pelajaran dan berdampak pada hasil belajarnya. Berdasarkan hasil belajar siswa di kelas IV SDN 1 Ngadisanan menunjukkan para siswa merasa kesulitan dalam pembelajaran IPS. Sedangkan prestasi belajar IPS kelas IV masih rendah jika dibandingkan dengan mata pelajaran lain seperti PKn, Bahasa Indonesia, Matematika, dan IPA. Dikatakan prestasi belajar rendah, karena ditunjukkan dari nilai rata-rata siswa kelas IV dengan jumlah 27 siswa, yang terdiri dari siswa perempuan yang berjumlah 16 dan siswa laki-laki 11 untuk pelajaran IPS nilai rata-rata 65,94 belum mencapai KKM. Dimana KKM yang ditetapkan untuk pelajaran IPS kelas IV di SDN 1 Ngadisanan adalah 70. Untuk mengatasi masalah tersebut guru harus mampu menciptakan pembelajaran yang menarik dan menyenangkan agar siswa memiliki motivasi belajar yang tinggi. Salah satu cara untuk menumbuhkan motivasi siswa adalah dengan menggunakan multimedia dalam pembelajaran. Dengan multimedia diharapkan siswa dapat lebih konkrit dalam pembelajaran IPS yang berifat abstrak. Dengan multimedia siswa termotivasi dan merasa senang dalam mengikuti pembelajaran, sehingga dapat mencapai prestasi belajar yang maksimal. Penggunaan multimedia pembelajaran akan memberikan pengalaman belajar secara nyata bagi siswa kelas IV SD dengan disertai teks, gambar, video, dan hyperlink sehingga 
pembelajaran jauh lebih menarik dan bermakna. Jika menggunakan multimedia maka dapat meningkatkan motivasi dan prestasi belajar siswa pada pembelajaran IPS.

\section{Metode Penelitian}

Penelitian ini dilaksanakan di SDN 1 Ngadisanan, Kecamatan Sambit, Kabupaten Ponorogo. Penelitian ini dilaksanakan selama 6 bulan mulai Januari sampai dengan Juni 2019 di SDN 1 Ngadisanan Kecamatan Sambit Kabupaten Ponorogo. Pada penelitian ini, peneliti berusaha mendeskripsikan bentuk pembelajaran untuk meningkatkan pemahaman siswa dengan menerapkan pembelajaran IPS berbasis multimedia pada materi Keragaman Suku Bangsa dan Agama di Negeriku, maka dengan demikian data yang akan dikumpulkan dalam penelitian bersifat deskriptif yaitu mengenai uraian-uraian kegiatan pembelajaran siswa dan penelitian ini menggunakan pendekatan kualitatif dengan jenis penelitian tindak kelas. Subyek penelitian ini adalah siswa kelas IV SDN 1 Ngadisanan Kecamatan Sambit Kabupaten Ponorogo yang berjumlah 27 siswa yang terdiri 11 laki-laki dan 16 perempuan.

Teknik pengumpulan data yaitu observasi, tes, catataan lapangan, dan dokumentasi. Sedangkan penelitian tindakan kelas ini menggunakan model tindakan yang dikembangkan oleh Kemmis, McTaggart, danNixon (2013), yang meliputi empat komponen yaitu: perencanaan (planning), tindakan (acting), pengamatan (observing), dan refleksi (reflecting). Untuk menentukan keberhasilan penelitian ini dibutuhkan indikator kinerja penelitian yaitu 1) Kemauan, kemampuan, dan aktivitas dalam melaksanakan pembelajaran IPS dengan menggunakan multimedia , menyusun laporan, mempresentasi, dan berdiskusi. 2) Pemahaman konsep siswa dengan menggunakan multimedia dalam pembelajaran IPS. 3) $80 \%$ siswa termotivasi dalam belajar. 4) 75 $\%$ siswa tuntas belajar. Dalam pelaksanakan PTK ini analisis data dibedakan menjadi dua jenis yaitu: 1) Data Kuantitatif yaitu data yang berhubungan dengan motivasi belajar dengan perhitungan persentase. 2) Data Kualitatif digunakan untuk menentukan peningkatan proses belajar khususnya berbagai tindakan yang dilakukan oleh guru.

\section{Hasil dan Pembahasan}

Dari observasi yang telah dilakukan diperoleh gambaran awal bahwa guru menyampaikan materi masih menggunakan metode ceramah. Kegiatan guru masih mendominasi saat proses pembelajaran IPS. Siswa jarang mendapat kesempatan untuk berbicara, alhasil komunikasi hanya berjalan satu arah. Hal ini terbukti dari hasil nilai rata-rata pra siklus yaitu ketuntasan siswa pada mata pembelajaran IPS sebanyak 12 siswa atau 44\%. Jumlah siswa yang belum tuntas adalah 15 atau 56\%. Motivasi siswa dalam mengikuti pembelajaran mencapai 59\% sedangkan prestasi belajar yang diperoleh siswa sebesar 65,94. Terindikasi bahwa hasil belajar siswa pada mata pelajaran IPS kelas IV tergolong rendah, dan di bawah kriteria ketuntasan minimum yaitu KKM di SD Negeri 1 Ngadisanan 70 .

\section{a. Siklus I}

Capaian hasil pelaksanaan Siklus I, motivasi belajar siswa dengan multimedia mencapai $73 \%$, hal ini sudah mengalami peningkatan dibandingkan pada prasiklus (59\%) tetapi belum memenuhi indikator keberhasilan yang telah ditentukan yaitu 80\%.Perbandingan motivasi siswa pada prasiklus dan siklus I dapat dilihat pada gambar berikut ini : 


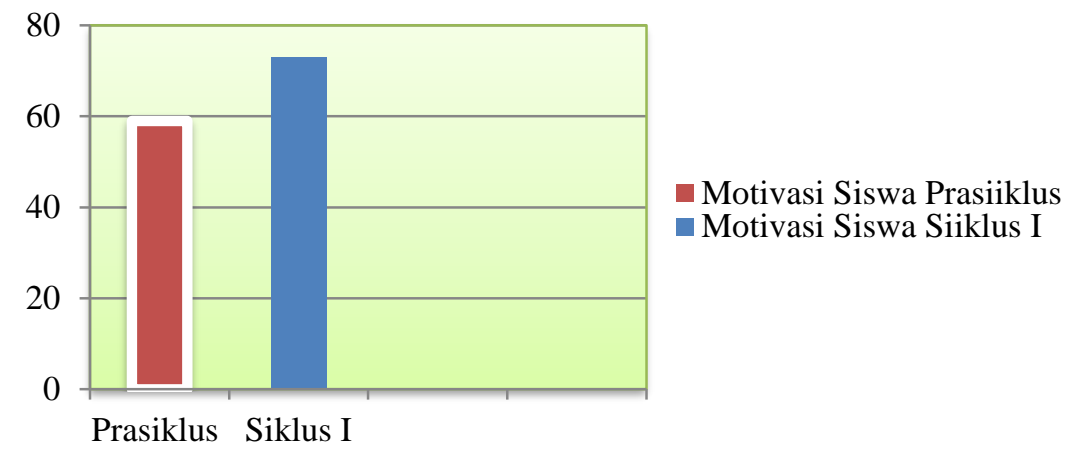

Gambar 1. Perbandingan Motivasi Belajar Prasiklus dan Siklus I

Sedangkan ketuntasan siswa pada mata pembelajaran IPS sebanyak 18 siswa atau 67\%. Jumlah siswa yang belum tuntas adalah 9 atau 33\%. Nilai rata-rata yang diperoleh siswa sebesar 69,81. Dari hasil belajar siswa pada mata pelajaran IPS kelas IV pada siklus I dengan menggunakan multimedia sudah adanya peningkatan terlihat dari hasil post tes siswa kelas IV persentase sudah meningkat. Tetapi masih ada beberapa siswa yang mendapat nilai di bawah kriteria ketuntasan minimum yaitu KKM. Perbandingan nilai rata-rata prasiklus dan siklus I dapat digambarkan seperti di bawah ini:

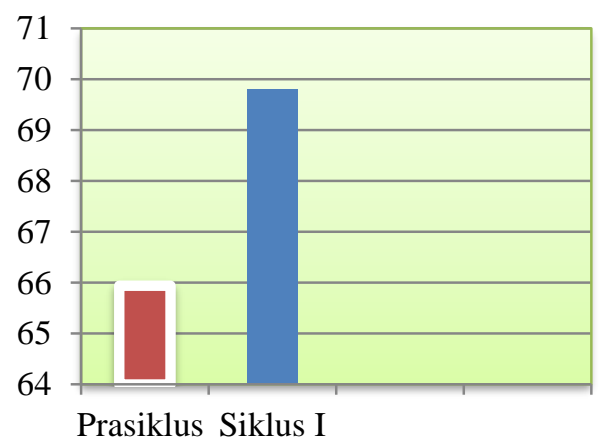

Gambar 2. Perbandingan Nilai Prasiklus dan Siklus I

Pada prasiklus, siswa yang mencapai KKM sebanyak 12 orang (44\%) dan yang tidak tuntas sebanyak 15 orang (56\%). Sedangkan pada siklus I, siswa yang mencapai KKM sebanyak 18 orang $(67 \%)$ dan yang tidak tuntas sebanyak 9 orang (33\%). Perbandingan capaian KKM tersebut dapat digambarkan seperti di bawah ini:

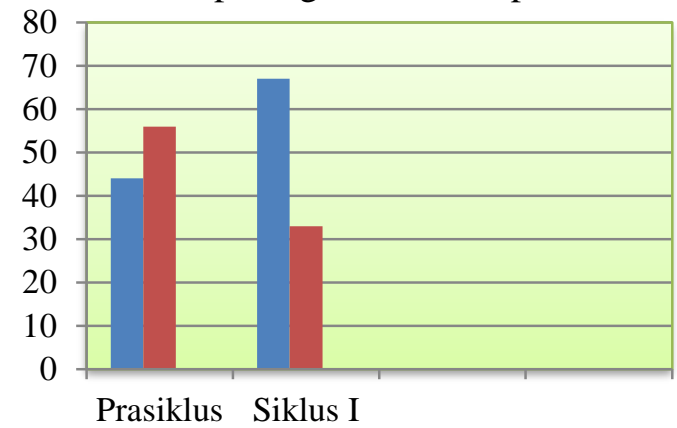

- Tuntas

Gambar 3. Perbandingan Capaian KKM Prasiklus dan Siklus I 


\section{b. Siklus II}

Siklus II pertemuan pertama dilaksanakan pada hari Senin tanggal 18 Februari 2019. Motivasi siswa dalam pembelajaran mencapai $85 \%$, hal ini sudah memenuhi indikator keberhasilan motivasi siswa yaitu $80 \%$. Perbandingan dan kenaikan motivasi pada siklus I dan siklus II tersebut dapat digambarkan seperti di bawah ini :

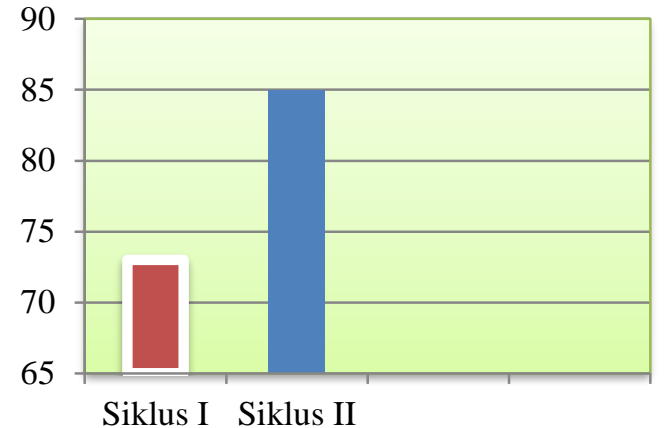

Gambar 4. Perbandingan Motivasi Belajar Siklus I dan Siklus II

Ketuntasan siswa pada mata pembelajaran IPS sebanyak 22 siswa atau $81 \%$. Jumlah siswa yang belum tuntas adalah 5 atau 19\%, nilai rata-rata yang diperoleh siswa sebesar 77,70. Tingkat ketuntasan klasikal sebesar $81 \%$ tersebut di atas sudah sesuai harapan atau karena sudah mencapai di atas indikator keberhasilan yang ditetapkan $\geq 75 \%$. Oleh karena itu penelitian berhenti pada siklus II. Perbandingan dan kenaikan nilai rata-rata siklus I dan siklus II dapat digambarkan di bawah ini :

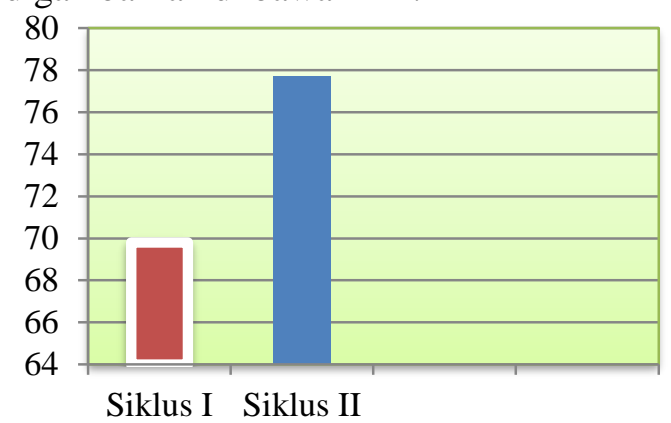

Gambar 5. Perbandingan Nilai Rata2 Siklus I dan Siklus II

Pada siklus II, siswa yang mencapai KKM sebanyak 22 orang (81\%) dan yang tidak tuntas sebanyak 7 orang (19\%). Sedangkan pada siklus I, siswa yang mencapai KKM sebanyak 18 orang $(67 \%)$ dan yang tidak tuntas sebanyak 9 orang (33\%). Perbandingan capaian KKM tersebut dapat digambarkan seperti di bawah ini:

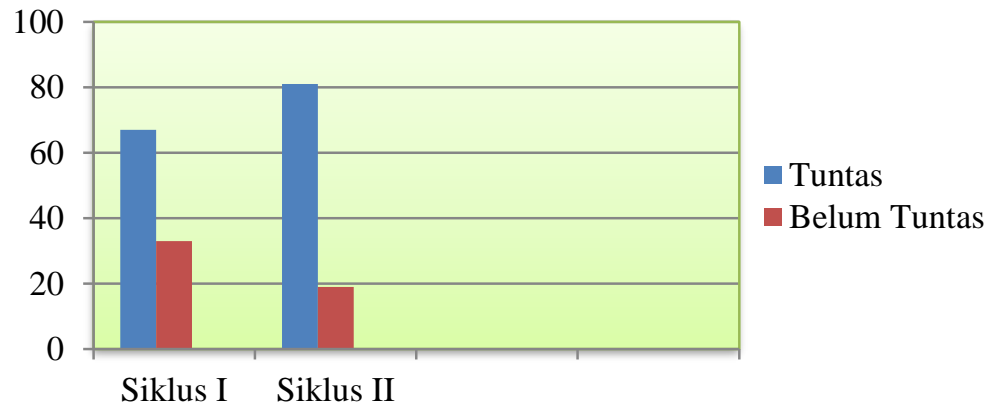

Gambar 6. Perbandingan Capaian KKM Siklus I dan Siklus II 
Dari hasil pelaksanaan tindakan penelitian sebagaimana disampaikan di atas menunjukkan bahwa penggunakan multimedia dapat meningkatkan motivasi dan prestasi belajar siswa kelas IV SD Negeri 1 Ngadisanan Kecamatan Sambit Kabupaten Ponorogo. Motivasi belajar siswa pada prasiklus 59\%, siklus I 73\% dan siklus II $85 \%$.

ini:

Persentase motivasi belajar siswa seperti di atas dapat ditunjukkan dalam gambar di bawah

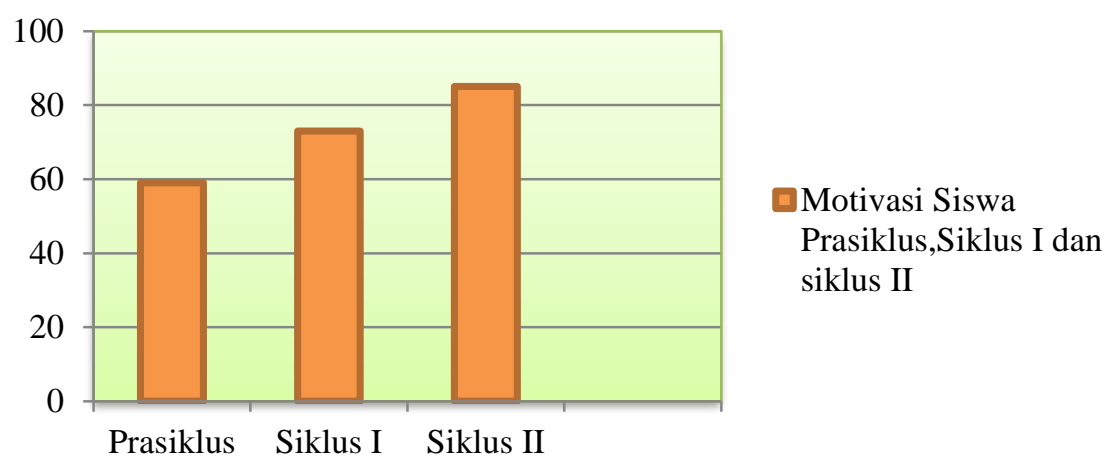

Gambar 7. Persentase Motivasi Siswa Prasiklus, Siklus I dan Siklus II

Sedangkan nilai prestasi belajar yang diraih siswa dari prasiklus $(65,94)$, siklus I $(69,81)$ dan siklus II $(77,70)$ mengalami peningkatan. Persentase nilai rata-rata klasikal seperti di atas dapat ditunjukkan dalam gambar di bawah ini:

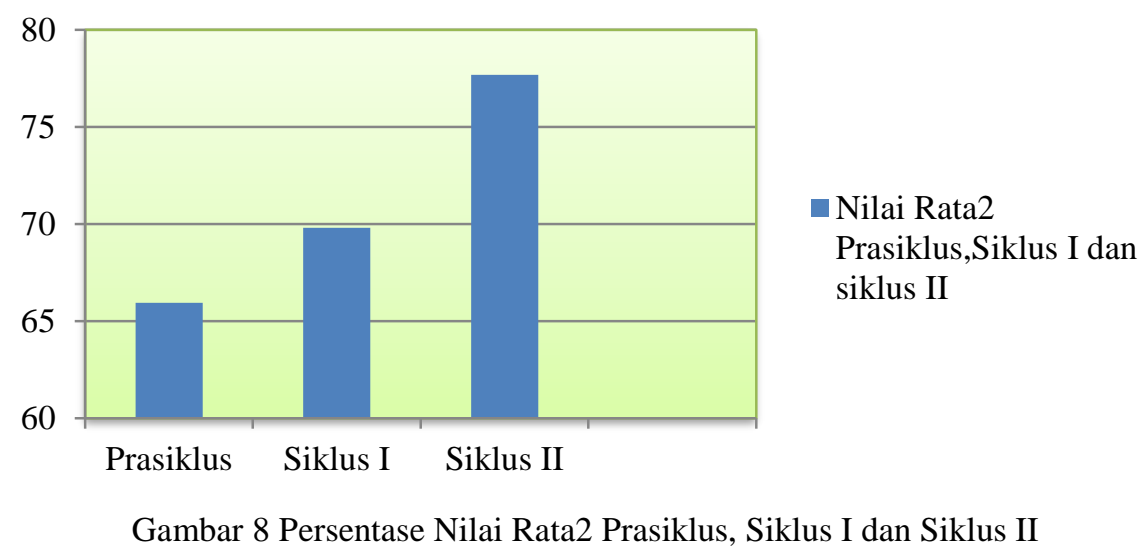

Siswa yang mencapai nilai di atas atau sama dengan Kriteria Ketuntasan Minimal (KKM) sebelum pemberian tindakan sampai dengan pemberian tindakan (siklus I dan siklus II) mengalami kenaikan, sebaliknya siswa yang tidak mencapai KKM mengalami penurunan. Hal tersebut dapat dilihat pada tabel di bawah ini

Tabel 1. Kriteria Capaian KKM Prasiklus, Siklus I dan Siklus II

\begin{tabular}{cccccccc}
\hline \multirow{2}{*}{$\begin{array}{c}\text { Kriteria } \\
\text { Capaian } \\
\text { KKM }\end{array}$} & KKM & $\begin{array}{c}\text { Jumlah } \\
\text { Siswa }\end{array}$ & $\begin{array}{c}\text { Persen } \\
\text { tase } \\
(\%)\end{array}$ & $\begin{array}{c}\text { Jumlah } \\
\text { Siswa }\end{array}$ & $\begin{array}{c}\text { Persen } \\
\text { tase } \\
(\%)\end{array}$ & $\begin{array}{c}\text { Jumlah } \\
\text { Siswa }\end{array}$ & $\begin{array}{c}\text { Persen } \\
\text { tase } \\
(\%)\end{array}$ \\
\hline Tuntas & $\geq 70$ & 12 & 44 & 18 & 67 & 22 & 81 \\
\hline
\end{tabular}




\begin{tabular}{cccccccc}
\hline Tidak Tuntas & $<70$ & 15 & 56 & 9 & 33 & 5 & 19 \\
\hline Jumlah & 27 & 100 & 27 & 100 & 27 & 100 \\
\hline
\end{tabular}

Nilai siswa berdasarkan KKM di atas dapat digambarkan sebagai berikut:

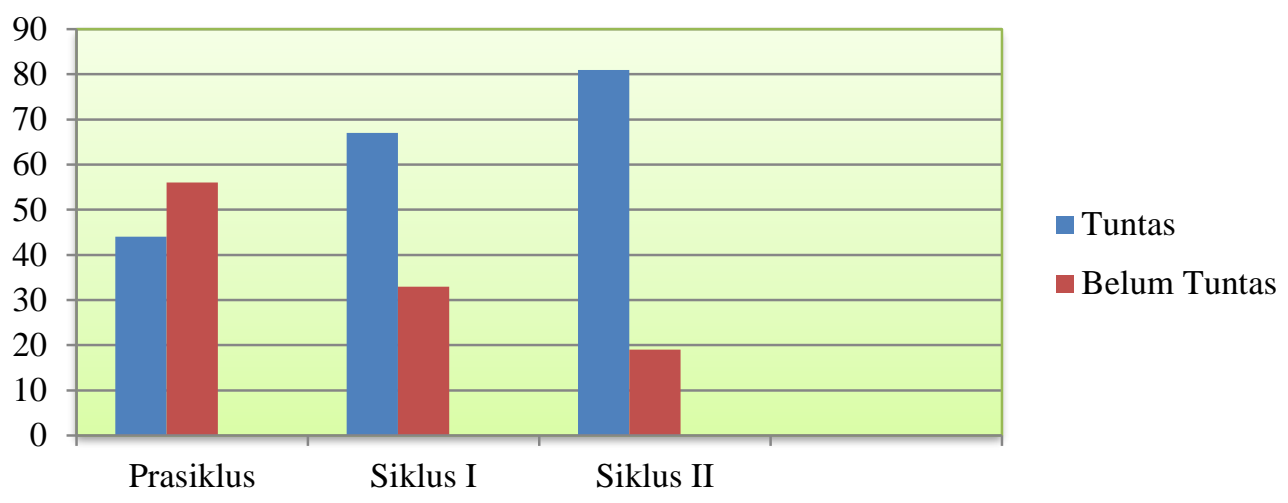

Gambar 9. Capaian KKM Prasiklus, Siklus I dan Siklus II

Pemanfataan multimedia dalam pembelajaran berdampak positif terhadap motivasi dan prestasi belajar siswa (Candra \& Masruri, 2015; Fanny \& Suardiman, 2013; Huda, 2016; Nurdiana, 2016; Priyanto, 2016).Penggunaan multimedia pada siklus II berjalan lebih baik dibandingkan pada siklus I guru sudah mengaplikasikan hasil rekomendasi dari refleksi siklus I. Hal yang dilakukan dengan cara memodifikasi media, memperbaiki kualitas gambar, video, dan hyperlink. Sedangkan kegiatan pembelajaran yang diperbaiki dari pembentukan kelompok dengan cara disamaratakan kemampuan akademik siswa, pemberian reward dan penugasan. Data yang dihasilkan pada siklus II ternyata sudah memenuhi indikator keberhasilan penelitian, sehingga penelitian tidak perlu dilanjutkan ke siklus berikutnya.

\section{Simpulan}

Berdasarkan hasil penelitian dan pembahasan yang di kemukakan dalam bab IV, simpulan yang dapat diambil dalam penelitian ini adalah penggunaan multimedia dapat meningkatkan motivasi dan prestasi belajar dalam pembelajaran IPS pada siswa kelas IV SD Negeri 1 Ngadisanan Kecamatan Sambit Kabupaten Ponorogo. Tahap pratindakan, menunjukkan bahwa motivasi dan prestasi belajar siswa kelas IV pada mata pelajaran IPS tergolong rendah. Motivasi belajar mencapai 59\%, nilai rata-rata kelas mencapai 65,94 sedangkan ketuntasan belajar sebesar $44 \%$. Pada siklus I, motivasi siswa mencapai 73\%, nilai rata-rata siswa 69,81 sedangkan ketuntasan belajar siswa mengalami peningkatan sebesar 23\% (kondisi awal 44\% meningkat menjadi $67 \%$ ). Pada siklus II, dengan adanya perbaikan dan modifikasi multimedia pembelajaran, disertai manajemen pembentukan kelompok dan pemberian reward, motivasi belajar siswa mencapai $85 \%$, nilai rata-rata siswa 77,70 dan ketuntasan belajar siswa mencapai $81 \%$. Prestasi belajar pada siklus II telah memenuhi indikator keberhasilan karena dari $\leq 75 \%$ siswa sudah mencapai KKM yaitu 70 .

\section{Daftar Pustaka}

Candra, A. A., \& Masruri, M. S. (2015). Pengembangan multimedia interaktif dengan pendekatan saintifik untuk pembelajaran PKn SMP. Harmoni Sosial: Jurnal Pendidikan IPS, 2(2), 109-114.

Cecep, K., \& Bambang, S. (2011). Media Pembelajaran Manual dan Digital. Ghalia Indonesia, Bogor. 
Fanny, A. M., \& Suardiman, S. P. (2013). Pengembangan multimedia interaktif untuk mata pelajaran ilmu pengetahuan sosial (IPS) sekolah dasar kelas V. Jurnal Prima Edukasia, l(1), 1-9.

Hamalik, O. (2000). Psikologi belajar dan mengajar: PT Sinar Baru Algensindo.

Huda, K. (2016). Pengembangan Multimedia Pembelajaran IPS Berbasis Heritage Untuk Meningkatkan Hasil Belajar Pada Siswa Smp Negeri Kota Madiun. Gulawentah: Jurnal Studi Sosial, 1(1), 24-33.

Kadji, Y. (2012). Tentang Teori Motivasi. Jurnal Inovasi, 9(01).

Kemmis, S., McTaggart, R., \& Nixon, R. (2013). The action research planner: Doing critical participatory action research: Springer Science \& Business Media.

Mayer, R., \& Mayer, R. E. (2005). The Cambridge handbook of multimedia learning: Cambridge university press.

Mayer, R. E. (2002). Multimedia learning. In Psychology of learning and motivation (Vol. 41, pp. 85-139): Elsevier.

Najjar, L. J. (1996). Multimedia information and learning. Paper presented at the Journal of educational multimedia and hypermedia.

Nurdiana, E. (2016). Penerapan Model Investigasi Kelompok Berbantuan Media Visual Untuk Meningkatkan Prestasi Belajar IPS SISWA KELAS IV SDN Sirapan 02. Gulawentah: Jurnal Studi Sosial, 1(1), 41-51.

Priyanto, W. (2016). Penerapan Multimedia Interaktif Berbasis Inkuiri Terbimbing Dalam Pembelajaran IPS Siswa Kelas IV Sekolah Dasar. Mimbar Sekolah Dasar, 3(2), 120-135.

Santoso, A. B., Yusro, A. C., Malawi, I., Hanif, M., \& Kokotiasa, W. (2019). Evaluation of the application of information technology and communication in lectures in the Primary School Teacher Education Study Program. Paper presented at the Journal of Physics: Conference Series.

Sardiman, A. M. (2012). Interaksi dan Motivasi Belajar Mengajar. Jakarta: PT Raja Grafindo Persada.

Setiawan, A. (2007). Dasar-dasar Multimedia Interaktif (MMI). Bandung: SPs UPI Banding.

Susanto, A. (2013). Teori belajar dan pembelajaran di sekolah dasar. In: Jakarta: Kencana prenada media group.

Uno, H. B. (2008). Teori motivasi dan pengukurannya. Jakarta: Bumi Aksara. 